\title{
Single Cell Stable Isotope Probing in Microbiology using Raman Microspectroscopy
}

\author{
Yun Wang ${ }^{1}$, Wei E. Huang ${ }^{2 *}$, Li Cui ${ }^{3}$, and Michael Wagner ${ }^{4}$
}

1. Shandong Provincial Key Laboratory Of Energy Genetics and Single Cell Center, Qingdao Institute of BioEnergy and Bioprocess Technology, Chinese Academy of Sciences, Qingdao, 266101, P. R. China.

2. Department of Engineering Science, University of Oxford, Parks Road, Oxford, OX1 3PJ, United Kingdom

3. Key Laboratory of Urban Environment and Health, Institute of Urban Environment, Chinese Academy of Sciences, Xiamen 361021, China

4. Division of Microbial Ecology, Department of Microbiology and Ecosystem Science, Research network 'Chemistry meets Microbiology', University of Vienna, 1090 Vienna, Austria

*Corresponding author

Wei E. Huang

Telephone: +44 (0)1865 283786; Fax: +44 (0)1865 374992

e-mail: wei.huang@eng.ox.ac.uk

Key Words: single cell, Raman spectroscopy, stable isotope probing, deuterium, metabolism 


\begin{abstract}
Microbial communities are essential for most ecosystem processes and interact in highly complex ways with virtually all eukaryotes. Thus, a detailed understanding of the function of such communities is a fundamental prerequisite for microbial ecologists, applied microbiologists and microbiome researchers. Using single cell Raman microspectroscopy, biochemical fingerprints of individual microbial cells can be obtained in a fast and nondestructive manner. If combined with stable isotope probing (SIP), Raman spectroscopy can directly reveal functions of single microorganisms in their natural habitat. This review provides an update on various SIP-approaches suitable for combination with different Raman scattering techniques and illustrates how single cell Raman SIP can be directly combined with the omics-centric analysis pipelines generally applied to investigate microbial communities.
\end{abstract}




\section{Introduction}

Understanding the function of microbial communities is a major challenge due to their often enormous diversity and the complexity of interactions occurring between community members and between them and the abiotic and biotic environment. Today, such communities can be directly studied using meta-omics approaches [1] and if combined with DNA-, RNA-, protein- or lipid-SIP, functional properties of community members are directly revealed [2-5]. While many fascinating discoveries were obtained with this toolbox, it (i) often fails to decipher functional differences between closely related community members, (ii) provides no information on functional differences between single cells of the same population, (iii) does not link genomic or functional information to individual cells as the basic unit of life and (iv) masks all spatial information on the occurrence of community members. The recent advent of single cell genomics [6,7] overcomes some of these limitations, although (i) obtaining closed genomes from single microbial cells is generally still not possible, and (ii) only a fraction of single-cell genomes can be recovered from a specific sample [8*]. Furthermore, transcriptomic and proteomic studies based on single microbial cells are still in their infancy [9] or (yet) not feasible. Consequently, SIP-techniques on single cells fill a major void in the toolbox of microbiologists as they enable direct observations of functional properties of individual microbial community members.

Isotope probing and simultaneous identification of single microbial cells within complex communities is possible since 1999 when the combination of fluorescence in situ hybridization (FISH) and microautoradiography was invented [10]. This approach is widely used in microbial ecology, but its dependency on radioisotopes limits substrate labelling options and applications. Furthermore, this technique is destructive and does not enable follow-up studies on cells with a certain function. During the last years single cell probing 
with stable isotopes became possible by analyzing microbial communities after incubation with labelled substrates with either secondary ion mass spectrometry (SIMS) or Raman microspectroscopy [11].

Different Raman techniques exist. For microbiological applications most frequently spontaneous Raman spectroscopy is applied. This technique measures the frequency change of incident photons due to energy exchange between molecular bonds and incident photons. The Raman band positions of a spontaneous Raman spectrum are independent from the wavelength of the incident photons although the intensity may vary to different incident photons. A Raman spectrum is typically presented in wavenumbers, which are the differences of inverse frequencies of the energy-changed photons and the inverse frequency of the incident photons. As a Raman spectrum reports vibrational, rotational, and other lowfrequency modes in a system which is defined by intrinsic properties of molecules, it represents a chemical fingerprint of a molecule or a system. Resonance Raman (RR) occurs when the frequency of the incident photons nearly coincides with the electronic excitation frequency of a molecule. Under RR conditions, the intensities of Raman bands from the molecule are selectively enhanced by a factor of $10^{3}$ to $10^{5}$. Surface-enhanced Raman scattering (SERS) also offers strongly enhanced Raman signals for those molecules being in very close spatial contact with rough metal surfaces or plasmonic nanostructures. For a more encompassing overview on the basic principles of these and other Raman techniques we refer the reader to reference [12]. Raman microspectroscopy offers a label-free and non-destructive way to obtain a chemical fingerprint of single microbial cells in their natural habitat [12] (Fig. 1). The spectroscopic analysis can be performed in water and requires virtually no sample preparation. The obtained single cell fingerprints enable direct identification of many storage compounds, pigments and other interesting compounds [13-17] (Fig. 1). However, identification of microbes living in their natural habitat based on these fingerprints is in most 
cases not possible, as the Raman fingerprint of a cell, indicating its chemical composition, changes with changing environmental conditions and is dependent on the growth stage of the analyzed cell. In this context it is important to keep in mind that Raman microspectroscopy can be directly combined with FISH and thus obtaining Raman spectra of microbes identified by rRNA-targeted nucleic acid probes within their habitat is possible [18,19] (Fig. 1). While the chemical composition of a cell can already contain hints to its function, more direct insights into functional properties can be obtained by directly combining stable isotope probing with ${ }^{15} \mathrm{~N}-,{ }^{13} \mathrm{C}$ - and ${ }^{2} \mathrm{H}$-isotopes and Raman microspectroscopy [17-22] (Fig. 1).

\section{SIP-Raman theory}

Raman spectra are generated due to inelastic light scattering when incident light and molecular bonds experience energy exchange. Taking one vibrational model as an example, diatomic molecules are thought as two masses $\left(\mathrm{m}_{1}\right.$ and $\left.\mathrm{m}_{2}\right)$ on a spring, and they have a reduced mass $\mu$ calculated by the equation $\mu=\frac{m_{1} m_{2}}{m_{1}+m_{2}}$ [23]. The wavenumber of the bond vibration $\left(\bar{v}, \mathrm{~cm}^{-1}\right)$ is described by the equation $\bar{v}=\frac{1}{2 \pi c} \sqrt{\frac{k}{\mu}}$, where $c$ is the speed of light $\left(\mathrm{ms}^{-}\right.$ $\left.{ }^{1}\right), k$ is the force constant of a diatomic bond $\left(\mathrm{Nm}^{-1}\right)$. Therefore, the wavenumber is inversely proportional to the square root of the reduced mass. When an atom is replaced by its heavier isotope, $\mu$ increases, leading to a smaller wavenumber. Taking deuterium substitution of hydrogen in $\mathrm{C}-\mathrm{H}$ bond as an example, $\mu$ is nearly doubled, leading to a new to original wavenumber ratio being 0.73 (for C-D replacement of C-H). In Raman-SIP, isotopedependent shifts of bands in single cell Raman spectra (SCRS) can be used as indicators for isotope incorporation after incubation experiments with an isotope-labeled substrate, whilst such shifts cannot be observed in cells from control experiments with an unlabeled substrate. The control experiments are essential when working with microbial communities in order to exclude that an unknown compound in an unlabeled cell has a Raman band that is used as an 
indicator for isotope incorporation. Interestingly, band shifts caused by isotope incorporation in microbial cells can also be observed with Fourier transform infrared (FT-IR) spectroscopy [24], but this method cannot be performed in the presence of water, has less distinguishably sharp spectral bands, lower spatial resolution and cannot be directly combined with FISH.

To date, most of the studies using SIP-Raman focused on ${ }^{13} \mathrm{C},{ }^{15} \mathrm{~N}$ and ${ }^{2} \mathrm{H}$ to replace their primordial isotopes $\left({ }^{12} \mathrm{C},{ }^{14} \mathrm{~N}\right.$ and $\left.{ }^{1} \mathrm{H}\right)$ respectively, and these applications will be discussed in this review in detail. Oxygen $(\mathrm{O})$ and sulfur $(\mathrm{S})$ isotopes can be potentially applied to SIPRaman, too, but to the best of our knowledge this has not been examined yet.

\section{${ }^{13}$ C-labeling for Raman-based single cell isotope probing}

${ }^{13} \mathrm{C}$-labeled compounds are most widely applied in SIP experiments with microbes and ${ }^{13} \mathrm{C}$ incorporation into the biomass of a microbial cell can be readily observed via Raman microspectroscopy. Huang et al. [20] showed that Raman spectra from individual Pseudomonas fluorescens cells grown with ${ }^{13} \mathrm{C}$-glucose as the sole carbon source contained bands at lower wavenumbers if compared to the spectra from unlabeled cells. The most prominent band shift appeared for the band at $1001 \mathrm{~cm}^{-1}$ in unlabeled cells, which is assigned to the symmetric benzene ring breathing mode (e.g. from phenylalanine), that shifted to 967 $\mathrm{cm}^{-1}$ in cells cultured with $100 \%{ }^{13} \mathrm{C}$-glucose. A more complete list of Raman band shifts after ${ }^{13} \mathrm{C}$ incorporation into cellular biomass is provided in Table 1 and a typical Raman shift of SCRS caused by ${ }^{13} \mathrm{C}$ incorporation is shown in Fig. 2A. The ratio of the $967 \mathrm{~cm}^{-1}$ to the $1001 \mathrm{~cm}^{-1}$ band increases with increasing amounts of incorporated carbon allowing to quantify the degree of labeling of the analyzed cells. Importantly, these SIP analyses are also possible with paraformaldehyde-fixed cells for FISH and can thus directly be combined with the identification of microbes by fluorescently labeled probes [18]. For example, the SIP- 
Raman-FISH technology was applied to a naphthalene contaminated groundwater sample and an uncultivated Acidovorax sp. was identified to play a key role in naphthalene degradation in situ $[18,19]$. Furthermore, using the above described band shift, it was demonstrated using incubation experiments with ${ }^{13} \mathrm{C}$-phenylalanine that elementary bodies of chlamydia are metabolically active outside of their host cells [25]. This finding obtain by Raman-based single cell SIP broke a long-lasting hypothesis in chlamydial biology that stated that the extracellular life stages of these intracellular bacteria are spore-like and metabolically inactive. This example also illustrates another important point for researchers interested in using single cell Raman-SIP in environmental samples. Many microbes can take up amino acids including phenylalanine from the environment. If phenylalanine is not synthesized de novo (and not applied as labeled derivative as in the above mentioned chlamydia experiment) by a bacterial cell then its $1001 \mathrm{~cm}^{-1}$ band will not shift in the presence of a ${ }^{13} \mathrm{C}$-labeled substrate like glucose or cellulose despite the fact that it is actively metabolizing the substrate [26*]. In such cases other ${ }^{13} \mathrm{C}$-induced band shifts have to be used for Raman-based SIP. More generally, this example illustrates that like all other SIP techniques, Raman-SIP is dependent on incorporation of the stable-isotope from the labeled substrate into the biomass.

${ }^{13} \mathrm{C}$-incorporation into cells can not only be observed via monitoring the symmetric benzene ring breathing mode. For example, in yeasts SIP experiments have been performed using shifts of a band at $1602 \mathrm{~cm}^{-1}$ (position in unlabeled cells) originating predominantly from the $\mathrm{C}=\mathrm{C}-\mathrm{C}=\mathrm{C}$ symmetric stretch of the 5,7-diene structure in ergosterol [27], but other band shifts have also been exploited [28]. In C. elegans the $1001 \mathrm{~cm}^{-1}$ phenylalanine band is masked by another band of unknown origin and could thus not be used for quantitative SIP predator-prey experiments with ${ }^{13} \mathrm{C}$-labeled E. coli offered as food to the nematode [29*]. However, this problem was solved by exploiting the Raman band at $747 \mathrm{~cm}^{-1}$ of cytochrome C (suggested to originate from thymine in the original paper) in the eukaryotic cells for quantifying ${ }^{13} \mathrm{C}$ - 
incorporation $\left[29^{*}\right]$. Cytochrome $\mathrm{c}$ is abundant in the mitochondria of eukaryotic cells and possesses a few strong and unique Raman bands at 747, 1128, 1311 and $1583 \mathrm{~cm}^{-1}$ if excited by a 532-nm laser due to Raman resonance scattering [30,31]. Furthermore, carotenoids of photosynthetic bacteria also show due to $\mathrm{RR}$ at a $532 \mathrm{~nm}$ excitation wavelength three very strong and characteristic bands that shift proportional to the ${ }^{13} \mathrm{C}$-content of the cells. This effect can be exploited for identifying and quantifying the activity of phototrophs in samples incubated with ${ }^{13} \mathrm{C}-\mathrm{NaHCO}_{3}$ via Raman microspectroscopy [17]. ${ }^{13} \mathrm{C}$-single-cell SIP using Raman microspectroscopy has a detection limit of about $10 \%{ }^{13} \mathrm{C} /{ }^{12} \mathrm{C}+{ }^{13} \mathrm{C}$ of a cell of interest if based on shifts of the symmetric benzene ring breathing mode [18] or carotenoid RR bands [17]. Due to the strong signals of the carotenoid RR bands SIP of phototrophs requires only very short measurement times enabling high-throughput counting of active cells in microfluidic chambers [32]. Recently, RR-SIP has also been exploited by targeting shifts of the cytochrome c bands in Geobacter metallireducens in order to observe the ${ }^{13} \mathrm{C}$-uptake of single bacterial cells [33**]. In the same study, ${ }^{13} \mathrm{C}$-incorporation into E. coli biomass could be observed by exploiting the very sensitive SERS technique. In the SERS spectra a band at $733 \mathrm{~cm}^{-1}$ that was assigned to adenine or adenine-containing molecules was shifted to 720 $\mathrm{cm}^{-1}$ in ${ }^{13}$ C-labeled E. coli cells [33**]. More generally, SERS has a few interesting characteristics that renders it attractive for microbial ecology studies [34,35]. It selectively enhances some Raman signals dependent on the properties of the applied nanoparticle and incident laser wavelength and this effect only happens at short distances within 1-4 nm range around nanoparticles. Furthermore, SERS might also be able to reduce the often problematic fluorescence interference to Raman signals (unpublished data). On the other hand, obtaining reproducible SERS signals with bacterial cells is very challenging and spectral assignment for spontaneous Raman bands may be inapplicable to SERS. 


\section{${ }^{15} \mathrm{~N}$-labeling for Raman-based single cell isotope probing}

Nitrogen consists of two stable isotopes, ${ }^{14} \mathrm{~N}$ and ${ }^{15} \mathrm{~N}$, and its fourteen radioactive isotopes are all short-lived, with the longest half-life being $9.965 \mathrm{~min}$. Therefore, radioisotope-based techniques are not suitable for $\mathrm{N}$ metabolism analysis. In Raman analysis, the red-shift caused by ${ }^{15} \mathrm{~N}$ substitution is not as large as that caused by ${ }^{13} \mathrm{C}$-replacement (Table 1) [21], and most red-shifts of the Raman bands are related to nucleic acids. [21,24,36] (Fig. 2B). Since Raman shifts caused by ${ }^{15} \mathrm{~N}$ replacement are buried in other Raman bands, it is not trivial to unequivocally identify ${ }^{15} \mathrm{~N}$-labeled cells in complex communities. It is thus not surprising that till today no reports on this have been published. However, we recently obtained promising results by combining the SERS method [37] with ${ }^{15} \mathrm{~N}$ labeling of microbial cells causing shifts of band at $728 \mathrm{~cm}^{-1}$ that was assigned to adenine ring breathing (pure adenine-containing compounds were used as controls). Interestingly, a linear correlation was observed between the extent of the band shift and the degree of ${ }^{15} \mathrm{~N}$-labeling of the cell (Fig. 3).

Recently, Muhamadali et al. [24] compared the Raman spectra of Escherichia coli biomass obtained under different ratios and combinations of ${ }^{13} \mathrm{C} /{ }^{12} \mathrm{C}$-glucose and ${ }^{15} \mathrm{~N} /{ }^{14} \mathrm{~N}$-ammonium chloride, as the sole carbon and nitrogen sources, respectively. Multivariate analyses of the spectra revealed clustering patterns directly correlated with the ratio of the isotopically labeled content of the medium. However, the Raman spectra of cells grown with combinations of both ${ }^{13} \mathrm{C}$ and ${ }^{15} \mathrm{~N}$ were dominated by the ratio of ${ }^{13} \mathrm{C}$ rather than both isotopes. Furthermore, it should be noted that most analyses reported in this publication were not performed on the single cell level but obtained from bulk measurements of concentrated biomass and that all data were obtained from cell harvested at the same growth stage, minimizing Raman spectra variations caused by other factors than incorporation of stable isotopes. Thus, double-labeling Raman-SIP studies using ${ }^{15} \mathrm{~N}$ and ${ }^{13} \mathrm{C}$-labeled substrates for 
analyzing function properties of microbial cells in complex communities is probably not feasible without further improvements.

\section{${ }^{2}$ H-labeling for Raman-based single cell isotope probing}

${ }^{2} \mathrm{H}$ (D)-labeling is often used to trace the metabolism of lipids and their storage patterns in eukaryotic cells via Raman microspectroscopy and Raman imaging as the the signals of CD stretching vibrations between 2000 and $2300 \mathrm{~cm}^{-1}$ can be easily detected by spontaneous Raman spectroscopy due to their location in an otherwise silent region [38] of the spectrum of cells [39,40]. Using Coherent anti-Stokes Raman Scattering (CARS) the sensitivity of imaging $-\mathrm{CD}_{2}$ stretching vibrations can be enhanced by several orders of magnitude compared to conventional Raman microscopy enabling monitoring of lipid metabolism in living eukaryotic cells with high temporal and spatial resolution [41]. In CARS spectral focusing of the laser energy into a single Raman band of interest occurs, but the resulting lack of spectral information can be overcome by combining CARS imaging with confocal Raman spectrometry using the same picosecond laser [42]. Different deuterated substrates have been used to monitor metabolic features of eukaryotic cells. For example, recently D-glucose labeling and Stimulated Raman Scattering (SRS) was applied to monitor lipogenesis in single living cells with high spatial and temporal resolution [43**]. Similarly, proteins can be metabolically labeled and detected using Raman spectroscopy by incubating cells with deuterated phenylalanine causing a shift of the $1001 \mathrm{~cm}^{-1}$ phenylalanine-band to $959 \mathrm{~cm}^{-1}$ [44]. Combination of labeling with deuterated amino acids and SRS imaging even allows generating spatial maps illustrating the ratio between newly synthesized and total proteins in mammalian cells [45*]. Deuterium-labeled substrates were also successfully used for Ramanbased single cell SIP of microbes [22**,33], but it should be noted that depending on the 
labeled substrate offered and the metabolic pathways present in the target organisms, not all compounds in the cell will become deuterated. For example, growth of Geobacter metallireducens GS-15 with ${ }^{2} \mathrm{H}$-acetate did not cause any shift of cytochrome $c$ Raman bands $\left[33^{* *}\right]$.

Studies exploiting isotope-labeled substrates for functional analyses of microbial communities have two important limitations. Firstly, isotopically labeled derivatives of many substrates of interest are very expensive or not even commercially available. Secondly, addition of labeled substrates changes the composition of the natural substrate pool, and thus might change the activities of community members. SIP studies using labeled water $[5,46]$ are helpful to circumvent these problems, but were until recently not explored for single cell isotope probing. In 2015 Berry et al. [22**] demonstrated using deuterated water $\left(\mathrm{D}_{2} \mathrm{O}\right)$ that the incorporation of deuterium into the biomass (mainly during the reductive steps of lipid biosynthesis [47]) of active bacterial and archaeal community members can be unambiguously detected via the newly-appearing C-D signature Raman band (2040 - 2300 $\mathrm{cm}^{-1}$ ). A typical Raman shift of SCRS caused by ${ }^{2} \mathrm{H}$ (D) incorporation is shown in Fig. $2 \mathrm{C}$. This Raman signature band is already detectable before cell division has been completed and occurs in fast growing cells after 20 minutes. This method, which can also be combined with FISH $[22 * *]$, thus allows microbiologists to recognize and identify all metabolically active members of a microbial community on the single cell level. Ideally, samples are concentrated before addition of heavy water in order to finally reconstitute the natural substrate concentrations. Furthermore, heavy water labeling can also be exploited for hunting microbes metabolizing any substrate of interest. For this purpose, $\mathrm{D}_{2} \mathrm{O}$ is added in combination with the unlabeled substrate and those microbes (identified by FISH) showing increased deuterium incorporation compared to a control experiment without added unlabeled substrate represent cells stimulated by the added substrate. The suitability of this approach for investigating 
complex microbial communities was demonstrated by identifying degraders of several complex carbohydrates in mice cecum microbiota [22**] and quantifying active microbial cells in native as well as glucose-amended soils [26*].

Given the clear Raman band shifts caused by ${ }^{13} \mathrm{C}$ or deuterium incorporation into the biomass of microbial cells, it seems likely that double-labeling studies with these isotopes to investigate microbial community members will be possible in the future.

\section{Combining SIP-Raman with Single Cell Genomics}

Due to its non-destructive nature, single cell Raman-SIP can also be used to sort microbial cells with a certain function from a complex microbial community for subsequent genomic analyses. After an initial proof of principle experiment with ${ }^{13} \mathrm{C}$-labeled cells from pure cultures [48], Berry et al. sorted in a microcapillary individual deuterated cells from a mouse cecal microbial community after stimulation with unlabeled glucosamine or mucin in the presence of heavy water using an optical tweezers and subsequently successfully amplified their genomes using multiple displacement amplification [22**]. This approach is widely applicable, but still has a relatively low throughput. To overcome this limitation, we are currently developing an automated microfluidic-based Raman-SIP cell sorter for targeted high-throughput genomic anaylses of microbial cells labeled with stable isotopes.

\section{Conclusions and Outlook}

Raman-SIP using ${ }^{13} \mathrm{C}$-labeled or deuterated substrates including heavy water can now routinely be applied for functional analyses of microbial community members. Its nondestructive manner offers ample opportunities for sorting of cells with a desired function 
and enhancing standard single-cell genomic or metagenomic pipelines. And if combined with FISH, it is often an attractive alternative for more tedious FISH-microautoradiography [10] or FISH-NanoSIMS [11] analyses.

Nevertheless, there is still room for improvement. Undoubtedly, the biggest challenge is that spontaneous Raman signals are naturally weak, especially on the single cell level, causing a need for relatively long measurement times per cell (but still generally no more than some seconds). Raman signal enhancement can be achieved by advanced Raman techniques like RR, CARS, SRS and SERS, but while progress has been made in applying these techniques for measuring labeled cells, these techniques are either not yet widely available (CARS, SRS) or generally applicable (RR, SERS) especially in complex samples containing numerous impurities generating high background Raman signals.

Raman signal enhancement is also required to increase the throughput of automated RamanSIP cell sorters or for Raman imaging approaches in microbial consortia. Furthermore, the detection limit for stable isotopes in a single microbial cell as measured by single cell Raman-SIP is comparable with the one of bulk DNA or RNA stable isotope probing, but this method is significantly less sensitive than (destructive) NanoSIMS measurements. Another challenge is that Raman bands of microbial cells are often assigned to several compounds simultaneously (an overview of Raman band assignment for biological molecules is provided in supplementary Table S1). While this does not hamper the detection of labeled cells, it complicates interpretation of metabolic pathways contributing to isotope incorporation into cellular macromolecules. Further experimental and database comparison work is needed to improve band assignments. But even without these refinements, single cell Raman-SIP is already a valuable amendment of the toolbox of microbiologists interested in revealing the function of microbial cells directly in their natural environment. 


\section{Acknowledgement}

We acknowledge support from EPSRC (EP/M002403/1), NERC (NE/M002934/1) and BBSRC sLoLa, (BB/M000265/1) in the UK and NSFC (31400436), CAS (XDB15040100) in China. MW was supported by an ERC Advanced Grant (NITRICARE, 294343) as well as by the Emerging Technologies Opportunity Program, which is supported by the Office of Science of the US Department of Energy under Contract DE-AC02- 05CH11231.

\section{References}

1. Sheik CS, Jain S, Dick GJ: Metabolic flexibility of enigmatic SAR324 revealed through metagenomics and metatranscriptomics. Environ Microbiol 2014, 16:304-317.

2. Radajewski S, Ineson P, Parekh NR, Murrell JC: Stable-isotope probing as a tool in microbial ecology. Nature 2000, 403:646-649.

3. Manefield M, Whiteley AS, Griffiths RI, Bailey MJ: RNA stable isotope probing, a novel means of linking microbial community function to Phylogeny. Appl Environ Microb 2002, 68:5367-5373.

4. Wilmes P, Heintz-Buschart A, Bond PL: A decade of metaproteomics: Where we stand and what the future holds. Proteomics 2015, 15:3409-3417.

5. Wegener G, Bausch M, Holler T, Nguyen Manh T, Mollar XP, Kellermann MY, Hinrichs K-U, Boetius A: Assessing sub-seafloor microbial activity by combined stable isotope probing with deuterated water and ${ }^{13} \mathrm{C}$-bicarbonate. Environ Microbiol 2012, 14:1517-1527.

6. Blainey PC: The future is now: single-cell genomics of bacteria and archaea. Fems Microbiol Rev 2013, 37:407-427.

7. Rinke C, Schwientek P, Sczyrba A, Ivanova NN, Anderson IJ, Cheng J-F, Darling A, Malfatti S, Swan BK, Gies EA, et al.: Insights into the phylogeny and coding potential of microbial dark matter. Nature 2013, 499:431-437.

8. Clingenpeel S, Clum A, Schwientek P, Rinke C, Woyke T: Reconstructing each cell's genome within complex microbial communities-dream or reality? Front Microbiol 2014, 5:771-771.

* Very informative review on the opportunities and still existing limitations of single cell genomics.

9. Wang J, Chen L, Chen Z, Zhang W: RNA-seq based transcriptomic analysis of single bacterial cells. Integr Biol 2015, 7:1466-1476.

10. Lee N, Nielsen PH, Andreasen KH, Juretschko S, Nielsen JL, Schleifer KH, Wagner M: Combination of fluorescent in situ hybridization and microautoradiography - a new tool for structure-function analyses in microbial ecology. Appl Environ Microb 1999, 65:1289-1297. 
11. Wagner M: Single-cell ecophysiology of microbes as revealed by Raman microspectroscopy or secondary ion mass spectrometry Imaging. Annu Rev Microbiol 2009, 63:411-429.

12. Li M, Xu J, Romero-Gonzalez M, Banwart SA, Huang WE: Single cell Raman spectroscopy for cell sorting and imaging. Curr Opin Biotechnol 2012, 23:56-63.

13. Gruber-Vodicka HR, Dirks U, Leisch N, Baranyi C, Stoecker K, Bulgheresi S, Heindl NR, Horn M, Lott C, Loy A, et al.: Paracatenula, an ancient symbiosis between thiotrophic Alphaproteobacteria and catenulid flatworms. Proc Natl Acad Sci 2011, 108:12078-12083.

14. Briers Y, Staubli T, Schmid MC, Wagner M, Schuppler M, Loessner MJ: Intracellular vesicles as reproduction elements in cell wall-deficient $\mathrm{L}$-form bacteria. Plos One 2012, 7:e38514.

15. Majed N, Chernenko T, Diem M, Gu AZ: Identification of functionally relevant populations in enhanced biological phosphorus removal processes based on intracellular polymers profiles and insights into the metabolic diversity and heterogeneity. Environ Sci Technol 2012, 46:5010-5017.

16. Milucka J, Ferdelman TG, Polerecky L, Franzke D, Wegener G, Schmid M, Lieberwirth I, Wagner M, Widdel F, Kuypers MMM: Zero-valent sulphur is a key intermediate in marine methane oxidation. Nature 2012, 491:541-+.

17. Li M, Canniffe DP, Jackson PJ, Davison PA, FitzGerald S, Dickman MJ, Burgess JG, Hunter CN, Huang WE: Rapid resonance Raman microspectroscopy to probe carbon dioxide fixation by single cells in microbial communities. Isme J 2012, 6:875-885.

18. Huang WE, Stoecker K, Griffiths R, Newbold L, Daims H, Whiteley AS, Wagner M: Raman-FISH: combining stable-isotope Raman spectroscopy and fluorescence in situ hybridization for the single cell analysis of identity and function. Environ Microbiol 2007, 9:1878-1889.

19. Huang WE, Ferguson A, Singer AC, Lawson K, Thompson IP, Kalin RM, Larkin MJ, Bailey MJ, Whiteley AS: Resolving genetic functions within microbial populations: in situ analyses using rRNA and mRNA stable isotope probing coupled with single-cell Raman-fluorescence in situ hybridization. Appl Environ Microb 2009, 75:234-241.

20. Huang WE, Griffiths RI, Thompson IP, Bailey MJ, Whiteley AS: Raman microscopic analysis of single microbial cells. Anal Chem 2004, 76:4452-4458.

21. Wang Y, Ji Y, Wharfe ES, Meadows RS, March P, Goodacre R, Xu J, Huang WE: Raman activated cell ejection for isolation of single cells. Anal Chem 2013, 85:10697-10701.

22. Berry D, Mader E, Lee TK, Woebken D, Wang Y, Zhu D, Palatinszky M, Schintimeister A, Schmid MC, Hanson BT, et al.: Tracking heavy water $\left(\mathbf{D}_{2} \mathbf{O}\right)$ incorporation for identifying and sorting active microbial cells. Proc Natl Acad Sci 2015, 112:E194E203.

** A universal Raman-SIP $\left({ }^{2} \mathrm{H}\right.$ incoporation) method to detect general metabolic activity of single microbial cells by simply adding heavy water was developed. The method can be directly combined with FISH and was also used to sort degraders of complex carbohydrates in a targeted manner from a gut sample for subsequent genome amplification.

23. Larkin P: Chapter 2 - Basic Principles. In Infrared and Raman Spectroscopy. Edited by Larkin P. Elsevier; 2011:7-25. 
24. Muhamadali H, Chisanga M, Subaihi A, Goodacre R: Combining Raman and FT-IR spectroscopy with quantitative isotopic labeling for differentiation of $E$. coli cells at community and single cell levels. Anal Chem 2015, 87:4578-4586.

25. Haider S, Wagner M, Schmid MC, Sixt BS, Christian JG, Haecker G, Pichler P, Mechtler $\mathrm{K}$, Mueller A, Baranyi C, et al.: Raman microspectroscopy reveals long-term extracellular activity of chlamydiae. Mol Microbiol 2010, 77:687-700.

26. Eichorst SA, Strasser F, Woyke T, Schintlmeister A, Wagner M, Woebken D: Advancements in the application of NanoSIMS and Raman microspectroscopy to investigate the activity of microbial cells in soils. Fems Microbiol Ecol 2015, 91:e38514.

*In this study heavy water labeling approach developed by Berry et al was succesfully applied to soil microbes. Furthermore, an important limitation of ${ }^{13} \mathrm{C}$-based RamanSIP in soils was discovered.

27. Noothalapati $\mathrm{H}$, Shigeto $\mathrm{S}$ : Exploring metabolic pathways in vivo by a combined approach of mixed stable isotope-labeled Raman microspectroscopy and multivariate curve resolution analysis. Anal Chem 2014, 86:7828-7834.

28. Venkata HNN, Shigeto S: Stable isotope-labeled Raman imaging reveals dynamic proteome localization to lipid droplets in single fission yeast cells. Chem Biol 2012, 19:1373-1380.

29. Li M, Huang WE, Gibson CM, Fowler PW, Jousset A: Stable isotope probing and Raman spectroscopy for monitoring carbon flow in a food chain and revealing metabolic pathway. Anal Chem 2013, 85:1642-1649.

* In this report the potential of Raman-SIP for monitoring carbon flow within a food chain is illustrated.

30. Okada M, Smith NI, Palonpon AF, Endo H, Kawata S, Sodeoka M, Fujita K: Label-free Raman observation of cytochrome c dynamics during apoptosis. Proc Natl Acad Sci 2012, 109:28-32.

31. Paetzold R, Keuntje M, Theophile K, Mueller J, Mielcarek E, Ngezahayo A, Ahlften AA$\mathrm{v}$ : In situ mapping of nitrifiers and anammox bacteria in microbial aggregates by means of confocal resonance Raman microscopy. J Microbiol Meth 2008, 72:241248.

32. Li M, Ashok PC, Dholakia K, Huang WE: Raman-activated cell counting for profiling carbon dioxide fixing microorganisms. J Phys Chem A 2012, 116:6560-6563.

33. Kubryk P, Koelschbach JS, Marozava S, Lueders T, Meckenstock RU, Niessner R, Ivleva NP: Exploring the potential of stable isotope (resonance) Raman microspectroscopy and surface-enhanced Raman scattering for the analysis of microorganisms at single cell level. Anal Chem 2015, 87:6622-6630.

** Very through study that included the first demonstration of using SERS for highly reproducible Raman-SIP for microbial cells.

34. Camden JP, Dieringer JA, Zhao J, Van Duyne RP: Controlled plasmonic nanostructures for surface-enhanced spectroscopy and sensing. Acc Chem Res 2008, 41:1653-1661.

35. Haran G: Single-molecule Raman spectroscopy: a probe of surface dynamics and plasmonic fields. Acc Chem Res 2010, 43:1135-1143.

36. Huang WE, Li MQ, Jarvis RM, Goodacre R, Banwart SA: Shining Light on the Microbial World: The Application of Raman Microspectroscopy. In Advances in Applied Microbiology, Vol 70. Edited by Laskin AI, Sariaslani S, Gadd GM; 2010:153-186. 
37. Cui L, Chen P, Chen S, Yuan Z, Yu C, Ren B, Zhang K: In situ study of the antibacterial activity and mechanism of action of silver nanoparticles by surfaceenhanced Raman spectroscopy. Anal Chem 2013, 85:5436-5443.

38. Etchegoin PG, Le Ru EC, Meyer M: Evidence of natural isotopic distribution from single-molecule SERS. J Am Chem Soc 2009, 131:2713-2716.

39. Matthaeus C, Krafft C, Dietzek B, Brehm BR, Lorkowski S, Popp J: Noninvasive imaging of intracellular lipid metabolism in macrophages by Raman microscopy in combination with stable isotopic labeling. Anal Chem 2012, 84:8549-8556.

40. Stiebing C, Matthaeus C, Krafft C, Keller A-A, Weber K, Lorkowski S, Popp J:

Complexity of fatty acid distribution inside human macrophages on single cell level using Raman micro-spectroscopy. Anal Bipanal Chem 2014, 406:7037-7046.

41. Xie XS, Yu J, Yang WY: Perspective - Living cells as test tubes. Science 2006, 312:228-230.

42. Slipchenko MN, Le TT, Chen $\mathrm{H}$, Cheng J-X: High-speed vibrational imaging and spectral analysis of lipid bodies by compound Raman microscopy. J Phys Chem $B$ 2009, 113:7681-7686.

43. Li J, Cheng J-X: Direct visualization of de novo lipogenesis in single living cells. Sci Rep 2014, 4.

**Impressive SRS-based imaging of deuterium-labeled lipids in cancer cells.

44. van Manen H-J, Lenferink A, Otto C: Noninvasive imaging of protein metabolic labeling in single human cells using stable isotopes and Raman microscopy. Anal Chem 2008, 80:9576-9582.

45. Wei L, Yu Y, Shen Y, Wang MC, Min W: Vibrational imaging of newly synthesized proteins in live cells by stimulated Raman scattering microscopy. Proc Natl Acad Sci 2013, 110:11226-11231.

* Innovative application of Raman imaging for cell biology research.

46. Schwartz E: Characterization of growing microorganisms in soil by stable isotope probing with $\left(\mathbf{H}_{2} \mathbf{O}\right)-\mathbf{O}-18$. Appl Environ Microb 2007, 73:2541-2546.

47. Valentine DL, Sessions AL, Tyler SC, Chidthaisong A: Hydrogen isotope fractionation during $\mathrm{H}_{2} / \mathrm{CO}_{2}$ acetogenesis: hydrogen utilization efficiency and the origin of lipid-bound hydrogen. Geobiology 2004, 2:179-188.

48. Huang WE, Ward AD, Whiteley AS: Raman tweezers sorting of single microbial cells. Environ Microbiol Rep 2009, 1:44-49. 
Table 1 Major Raman bands shifted in microbial cells due to isotope substitution. It should be noted that in isotope labeling experiments depending on the type of substrate and the metabolic pathways expressed in the analyzed cell not all shifts reported here must always be detectable. Band shifts will only occur if the isotope is actually incorporated into the respective molecule within the cell.

\begin{tabular}{|c|c|c|c|c|}
\hline $\begin{array}{l}\text { Raman bands } \\
\text { of unlabeled } \\
\text { cells }\left(\mathrm{cm}^{-1}\right)\end{array}$ & Isotope & $\begin{array}{l}\text { The extent of } \\
\text { Raman shift }\left(\mathrm{cm}^{-1}\right)\end{array}$ & Assignment & References \\
\hline 787 & ${ }^{13} \mathrm{C}$ & -17 & $\begin{array}{l}\text { O- P- O breathing, Cytosine, } \\
\text { uracil }\end{array}$ & [20] \\
\hline $1001-1003$ & ${ }^{13} \mathrm{C}$ & -37 & $\begin{array}{l}\text { Symmetric ring breathing } \\
\text { mode of phenylalanine }\end{array}$ & [20] \\
\hline 1247 & ${ }^{13} \mathrm{C}$ & -14 & Amide III & {$[20]$} \\
\hline 1342 & ${ }^{13} \mathrm{C}$ & -15 & $\mathrm{CH}$ stretching of adenine & {$[20]$} \\
\hline 1578 & ${ }^{13} \mathrm{C}$ & -47 & $\begin{array}{l}\text { Ring stretching of guanine } \\
\text { and adenine }\end{array}$ & [20] \\
\hline 1663 & ${ }^{13} \mathrm{C}$ & -35 & $\begin{array}{l}\mathrm{C}=\mathrm{C} \text { of unsaturated lipid, } \\
\text { amide I }\end{array}$ & [20] \\
\hline 729 & ${ }^{15} \mathrm{~N}$ & -14 & Adenine ring breathing & [21] \\
\hline 787 & ${ }^{15} \mathrm{~N}$ & -3 & $\begin{array}{l}\text { O- P- O breathing, Cytosine, } \\
\text { uracil }\end{array}$ & {$[21]$} \\
\hline 1174 & ${ }^{15} \mathrm{~N}$ & -10 & $\begin{array}{l}\mathrm{C}-\mathrm{H} \text { in-plane bending of } \\
\text { tyrosine or phenylalanine }\end{array}$ & {$[21]$} \\
\hline 1247 & ${ }^{15} \mathrm{~N}$ & -14 & Amide III & [21] \\
\hline 1342 & ${ }^{15} \mathrm{~N}$ & -19 & $\mathrm{CH}$ stretching of adenine & {$[21]$} \\
\hline 1480 & ${ }^{15} \mathrm{~N}$ & -10 & $\begin{array}{l}\text { Purine base of guanine and } \\
\text { adenine }\end{array}$ & [21] \\
\hline 1578 & ${ }^{15} \mathrm{~N}$ & -7 & $\begin{array}{l}\text { Ring stretching of guanine } \\
\text { and adenine }\end{array}$ & {$[21]$} \\
\hline $1001-1003$ & ${ }^{2} \mathrm{H}$ & -42 & $\begin{array}{l}\text { Symmetric ring breathing } \\
\text { mode of phenylalanine }\end{array}$ & {$[44]^{*}$} \\
\hline$\sim 2850$ & ${ }^{2} \mathrm{H}$ & -745 & $\mathrm{CH}$ stretching of lipid & {$[41]^{* *}$} \\
\hline $2800-3100$ & ${ }^{2} \mathrm{H}$ & -800 & $\begin{array}{l}\mathrm{CH} \text { stretching of lipid and } \\
\text { protein }\end{array}$ & {$[22]$} \\
\hline
\end{tabular}

\footnotetext{
* D-phenylalanine rather than $\mathrm{D}_{2} \mathrm{O}$ was used;
} **measured by CARS

\section{Figure legends}


Figure 1. Overview on SIP-Raman technology. Upper panel: Typical single cell Raman spectrum showing signature peaks of poly-3-hydroxybutyrate $(830,1059,1103,1451,1735$ $\left.\mathrm{cm}^{-1}\right)$ and polyphosphate $\left(1176 \mathrm{~cm}^{-1}\right)$ as storage products. Furthermore, the typical cytochrome peaks from RR are visible (749, 1129, 1311 and $1586 \mathrm{~cm}^{-1}$ ). See also supplementary Table S1 for assignment of Raman bands to biological molecules. Lower panel: Combination of FISH (left) with Raman-SIP (right) using ${ }^{13} \mathrm{C}$-labeled naphthalene in a groundwater microbial community. Depicted Raman spectra are from FISH identified Pseudomonas sp. (green) and Acidovorax sp. (red) cells.

Figure 2. Shifts of Bands in SCRS caused by incorporation of different stable isotopes. (A) fully ${ }^{13}$ C-labeled E. coli (red) and unlabeled E.coli (blue). (B) Fully ${ }^{15} \mathrm{~N}$-labeled E.coli (red) and unlabeled E.coli (blue). A few bands, such as $729 \mathrm{~cm}-1$ (adenine ring breathing), 787 (cytosine, uracil ring breathing), 1176 (guanine ring stretching), 1247 (Amide III), 1341 (nucleic acid vibration mode), and $1577 \mathrm{~cm}^{-1}$ (guanine, adenine ring stretching) are significantly shifted due to ${ }^{15} \mathrm{~N}$ incorporation. (C) Deuterated E.coli (red) due to growth in $40 \%$ $\mathrm{D}_{2} \mathrm{O}$-containing medium and unlabeled E.coli (blue). Depending on the metabolism of the microbial cell (e.g. autotrophic vs. heterotrophic) additional deuterium-induced peak shifts might occur. It should be noted that the exact position of bands shifting due to isotope incorporation sometimes varies in different publications. This is often caused by the use of different gratings causing different spectral resolution.

Figure 3. SERS spectra of single E. coli DH5a cells with different levels of ${ }^{15} \mathrm{~N}$ incorporation when growing in various concentrations of ${ }^{15} \mathrm{~N}-\mathrm{NH}_{4} \mathrm{Cl}$. The detection limit is $10 \%{ }^{15} \mathrm{~N}$ incorporation $(\mathrm{P}<0.05)$. The power of the $532-\mathrm{nm}$ laser on single cells was $0.05 \mathrm{~mW}$. (A) A sharp and clear Raman band at $728 \mathrm{~cm}^{-1}$ (adenine like compound) shifted due to ${ }^{15} \mathrm{~N}$ incorporation into cellular biomass. (B) Relationship between the ${ }^{15} \mathrm{~N}$ ratio in single cells and Raman shift. 
Table 1 Major Raman bands shifted in microbial cells due to isotope substitution. It should be noted that in isotope labeling experiments depending on the type of substrate and the metabolic pathways expressed in the analyzed cell not all shifts reported here must always be detectable. Band shifts will only occur if the isotope is actually incorporated into the respective molecule within the cell.

\begin{tabular}{|c|c|c|c|c|}
\hline $\begin{array}{l}\text { Raman bands } \\
\text { of unlabeled } \\
\text { cells }\left(\mathrm{cm}^{-1}\right)\end{array}$ & Isotope & $\begin{array}{l}\text { The extent of } \\
\text { Raman shift }\left(\mathrm{cm}^{-1}\right)\end{array}$ & Assignment & References \\
\hline 787 & ${ }^{13} \mathrm{C}$ & -17 & $\begin{array}{l}\mathrm{O}-\mathrm{P}-\mathrm{O} \text { breathing, Cytosine, } \\
\text { uracil }\end{array}$ & {$[20]$} \\
\hline $1001-1003$ & ${ }^{13} \mathrm{C}$ & -37 & $\begin{array}{l}\text { Symmetric ring breathing } \\
\text { mode of phenylalanine }\end{array}$ & [20] \\
\hline 1247 & ${ }^{13} \mathrm{C}$ & -14 & Amide III & {$[20]$} \\
\hline 1342 & ${ }^{13} \mathrm{C}$ & -15 & $\mathrm{CH}$ stretching of adenine & {$[20]$} \\
\hline 1578 & ${ }^{13} \mathrm{C}$ & -47 & $\begin{array}{l}\text { Ring stretching of guanine } \\
\text { and adenine }\end{array}$ & {$[20]$} \\
\hline 1663 & ${ }^{13} \mathrm{C}$ & -35 & $\begin{array}{l}\mathrm{C}=\mathrm{C} \text { of unsaturated lipid, } \\
\text { amide I }\end{array}$ & [20] \\
\hline 729 & ${ }^{15} \mathrm{~N}$ & -14 & Adenine ring breathing & {$[21]$} \\
\hline 787 & ${ }^{15} \mathrm{~N}$ & -3 & $\begin{array}{l}\text { O- P- O breathing, Cytosine, } \\
\text { uracil }\end{array}$ & {$[21]$} \\
\hline 1174 & ${ }^{15} \mathrm{~N}$ & -10 & $\begin{array}{l}\text { C-H in-plane bending of } \\
\text { tyrosine or phenylalanine }\end{array}$ & [21] \\
\hline 1247 & ${ }^{15} \mathrm{~N}$ & -14 & Amide III & {$[21]$} \\
\hline 1342 & ${ }^{15} \mathrm{~N}$ & -19 & $\mathrm{CH}$ stretching of adenine & {$[21]$} \\
\hline 1480 & ${ }^{15} \mathrm{~N}$ & -10 & $\begin{array}{l}\text { Purine base of guanine and } \\
\text { adenine }\end{array}$ & {$[21]$} \\
\hline 1578 & ${ }^{15} \mathrm{~N}$ & -7 & $\begin{array}{l}\text { Ring stretching of guanine } \\
\text { and adenine }\end{array}$ & {$[21]$} \\
\hline $1001-1003$ & ${ }^{2} \mathrm{H}$ & -42 & $\begin{array}{l}\text { Symmetric ring breathing } \\
\text { mode of phenylalanine }\end{array}$ & {$[44]^{*}$} \\
\hline$\sim 2850$ & ${ }^{2} \mathrm{H}$ & -745 & $\mathrm{CH}$ stretching of lipid & {$[41]^{* *}$} \\
\hline $2800-3100$ & ${ }^{2} \mathrm{H}$ & -800 & $\begin{array}{l}\mathrm{CH} \text { stretching of lipid and } \\
\text { protein }\end{array}$ & {$[22]$} \\
\hline
\end{tabular}

* D-phenylalanine rather than $\mathrm{D}_{2} \mathrm{O}$ was used; **measured by CARS

Figure legends 
Figure 1. Overview on SIP-Raman technology. Upper panel: Typical single cell Raman spectrum showing signature peaks of poly-3-hydroxybutyrate $(830,1059,1103,1451,1735$ $\left.\mathrm{cm}^{-1}\right)$ and polyphosphate $\left(1176 \mathrm{~cm}^{-1}\right)$ as storage products. Furthermore, the typical cytochrome peaks from RR are visible (749, 1129, 1311 and $1586 \mathrm{~cm}^{-1}$ ). See also supplementary Table S1 for assignment of Raman bands to biological molecules. Lower panel: Combination of FISH (left) with Raman-SIP (right) using ${ }^{13} \mathrm{C}$-labeled naphthalene in a groundwater microbial community. Depicted Raman spectra are from FISH identified Pseudomonas sp. (green) and Acidovorax sp. (red) cells.

Figure 2. Shifts of Bands in SCRS caused by incorporation of different stable isotopes. (A) fully ${ }^{13} \mathrm{C}$-labeled E. coli (red) and unlabeled E.coli (blue). (B) Fully ${ }^{15} \mathrm{~N}$-labeled E.coli (red) and unlabeled E.coli (blue). A few bands, such as $729 \mathrm{~cm}-1$ (adenine ring breathing), 787 (cytosine, uracil ring breathing), 1176 (guanine ring stretching), 1247 (Amide III), 1341 (nucleic acid vibration mode), and $1577 \mathrm{~cm}^{-1}$ (guanine, adenine ring stretching) are significantly shifted due to ${ }^{15} \mathrm{~N}$ incorporation. (C) Deuterated E.coli (red) due to growth in $40 \%$ $\mathrm{D}_{2} \mathrm{O}$-containing medium and unlabeled E.coli (blue). Depending on the metabolism of the microbial cell (e.g. autotrophic vs. heterotrophic) additional deuterium-induced peak shifts might occur. It should be noted that the exact position of bands shifting due to isotope incorporation sometimes varies in different publications. This is often caused by the use of different gratings causing different spectral resolution.

Figure 3. SERS spectra of single E. coli DH5a cells with different levels of ${ }^{15} \mathrm{~N}$ incorporation when growing in various concentrations of ${ }^{15} \mathrm{~N}-\mathrm{NH}_{4} \mathrm{Cl}$. The detection limit is $10 \%{ }^{15} \mathrm{~N}$ incorporation $(\mathrm{P}<0.05)$. The power of the $532-\mathrm{nm}$ laser on single cells was $0.05 \mathrm{~mW}$. (A) A sharp and clear Raman band at $728 \mathrm{~cm}^{-1}$ (adenine like compound) shifted due to ${ }^{15} \mathrm{~N}$ incorporation into cellular biomass. (B) Relationship between the ${ }^{15} \mathrm{~N}$ ratio in single cells and Raman shift. 


\section{Raman spectrum as phenotypic} fingerprint of a single cell

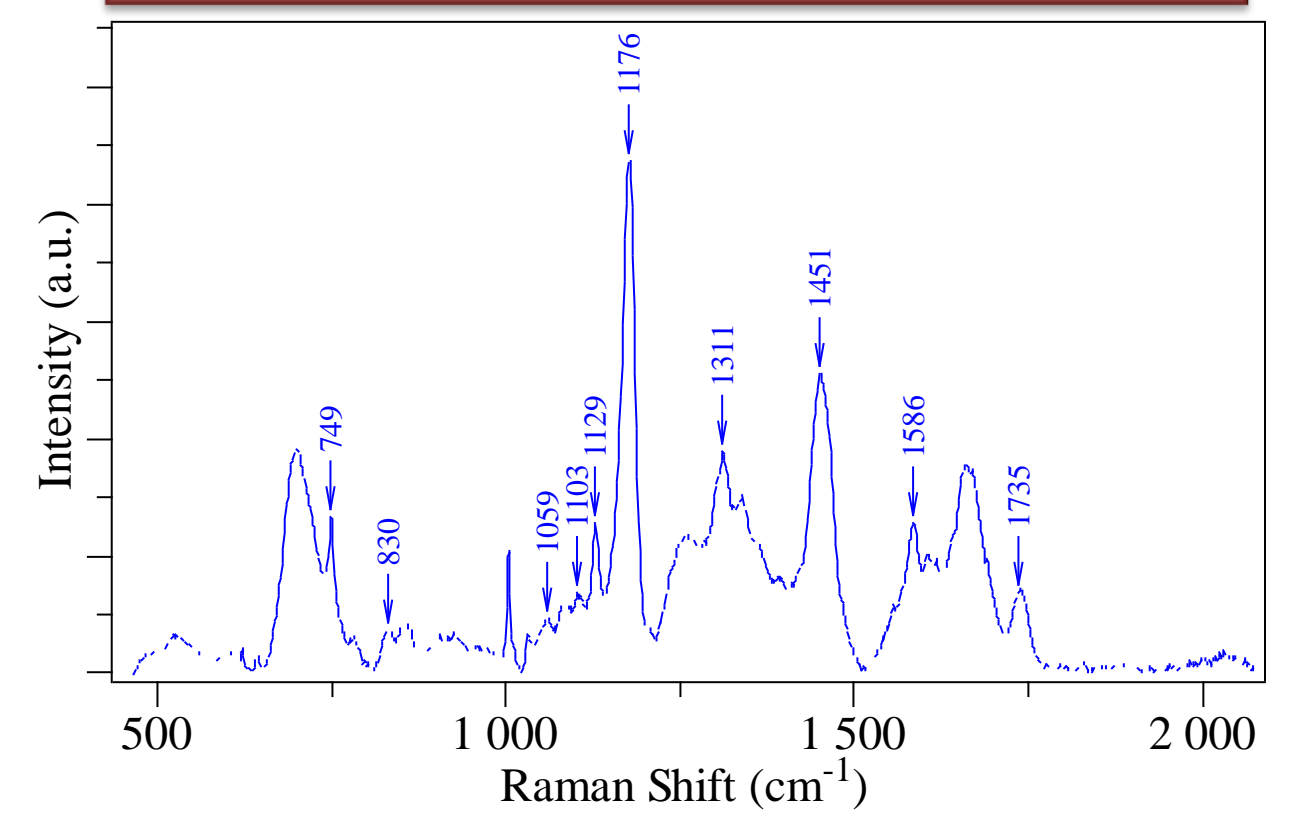

Single cell stable isotope probing

\section{Metabolism}
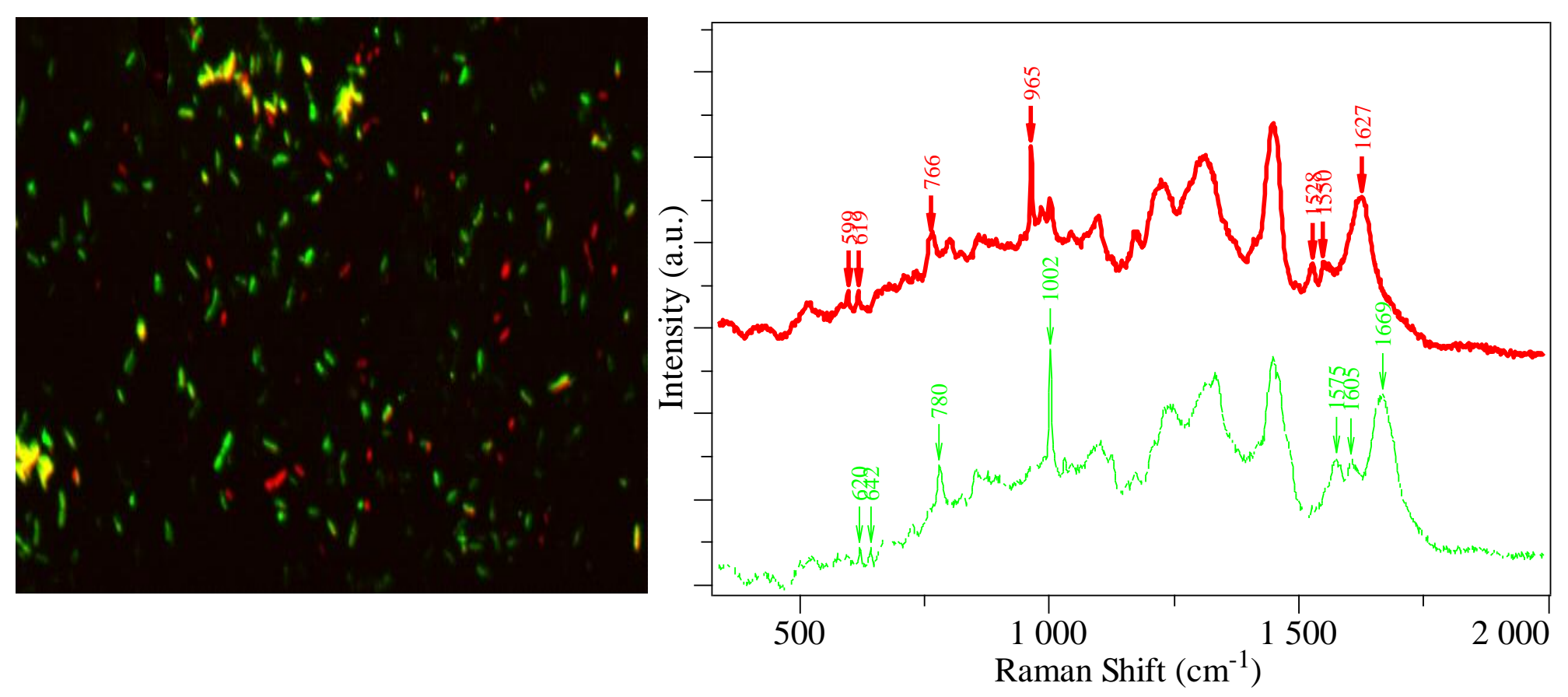
A

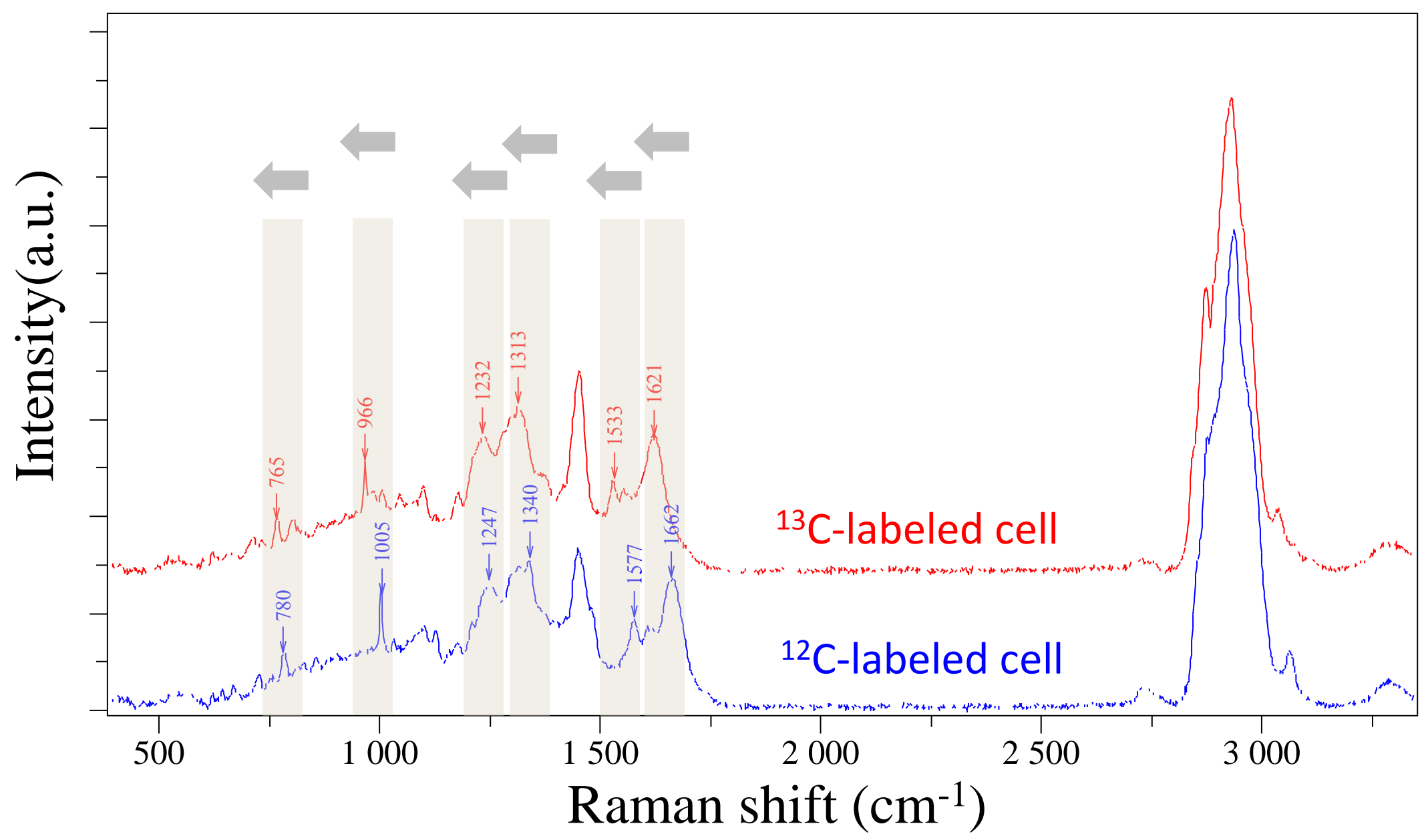

B

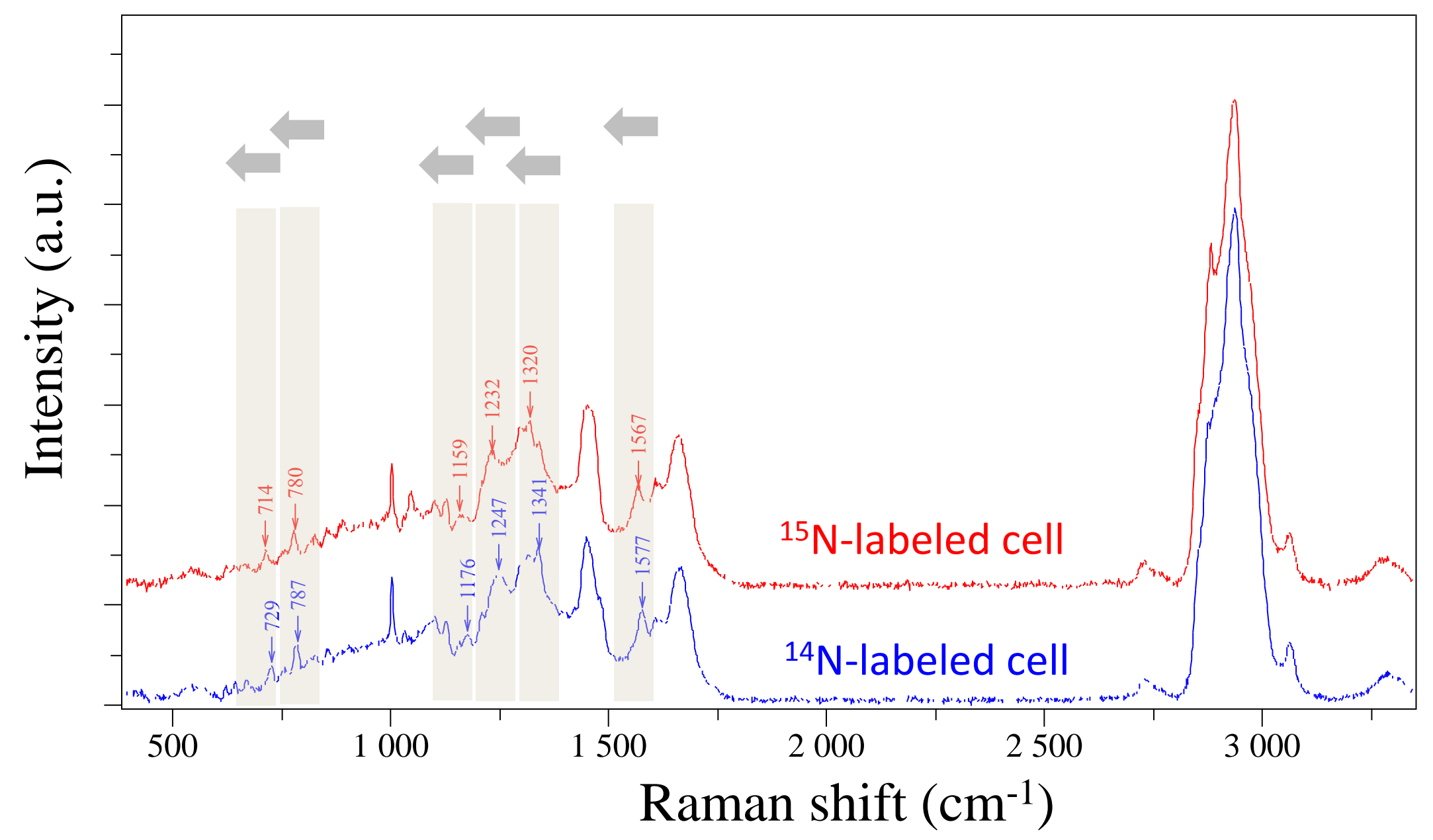


C

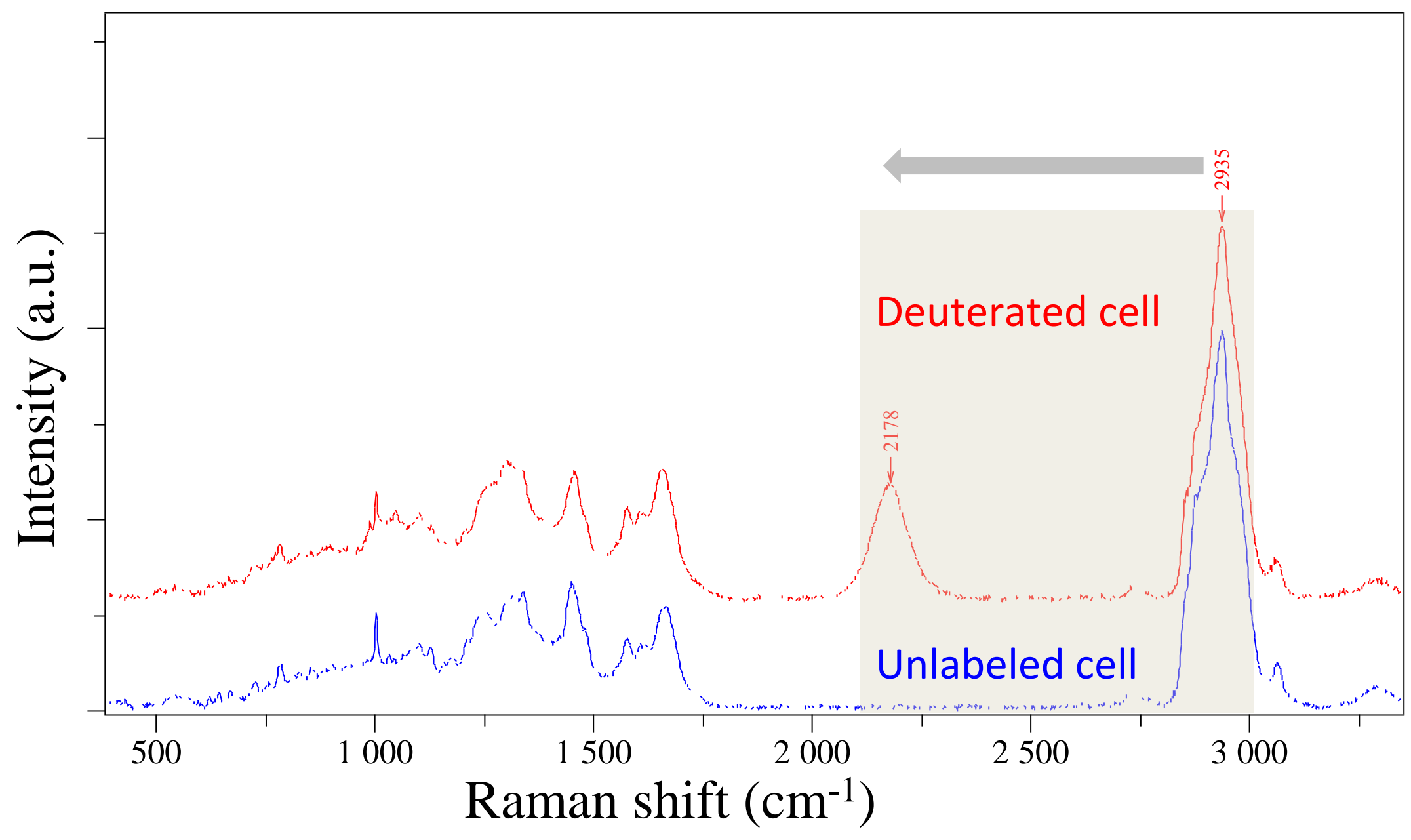


A

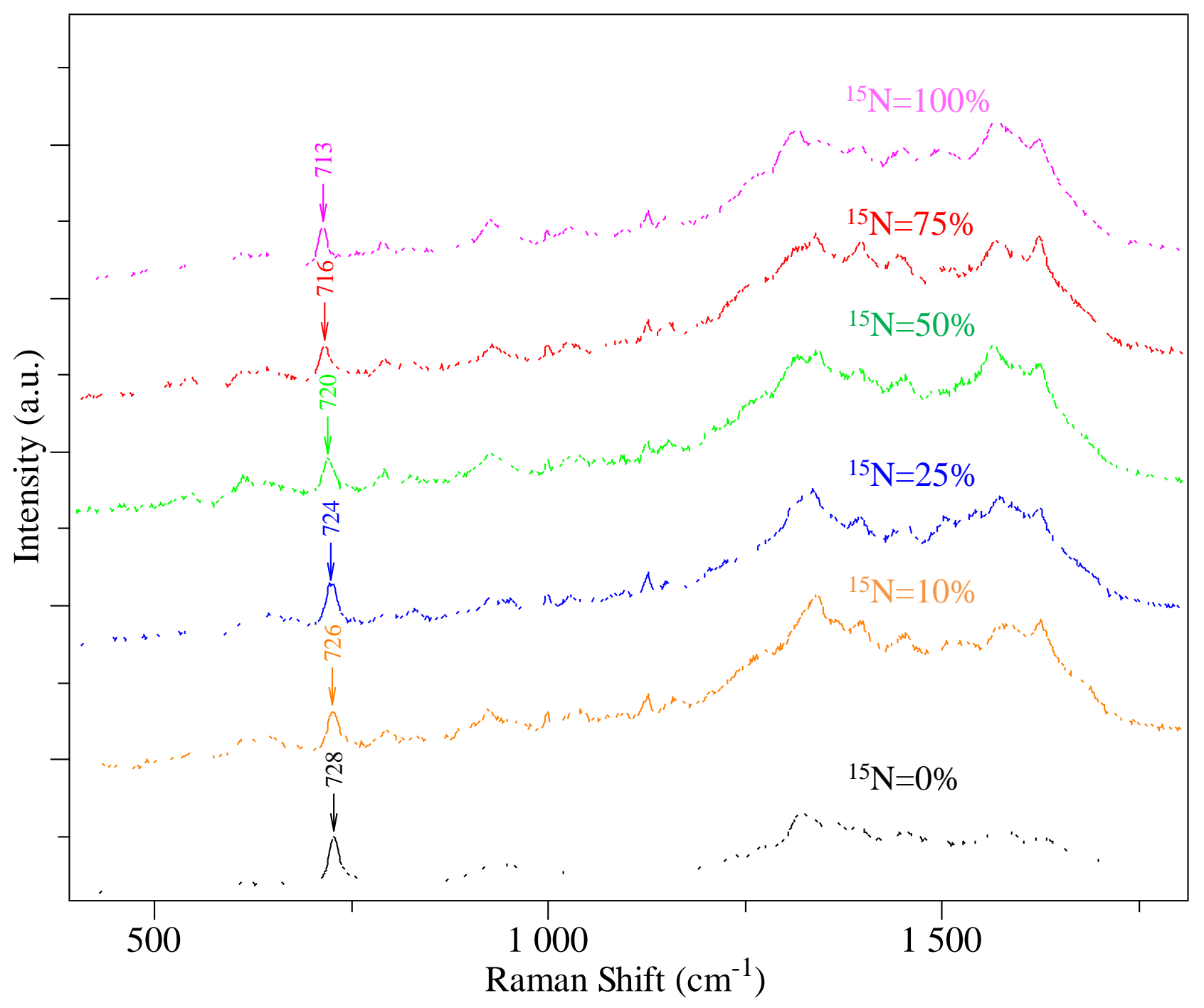

B

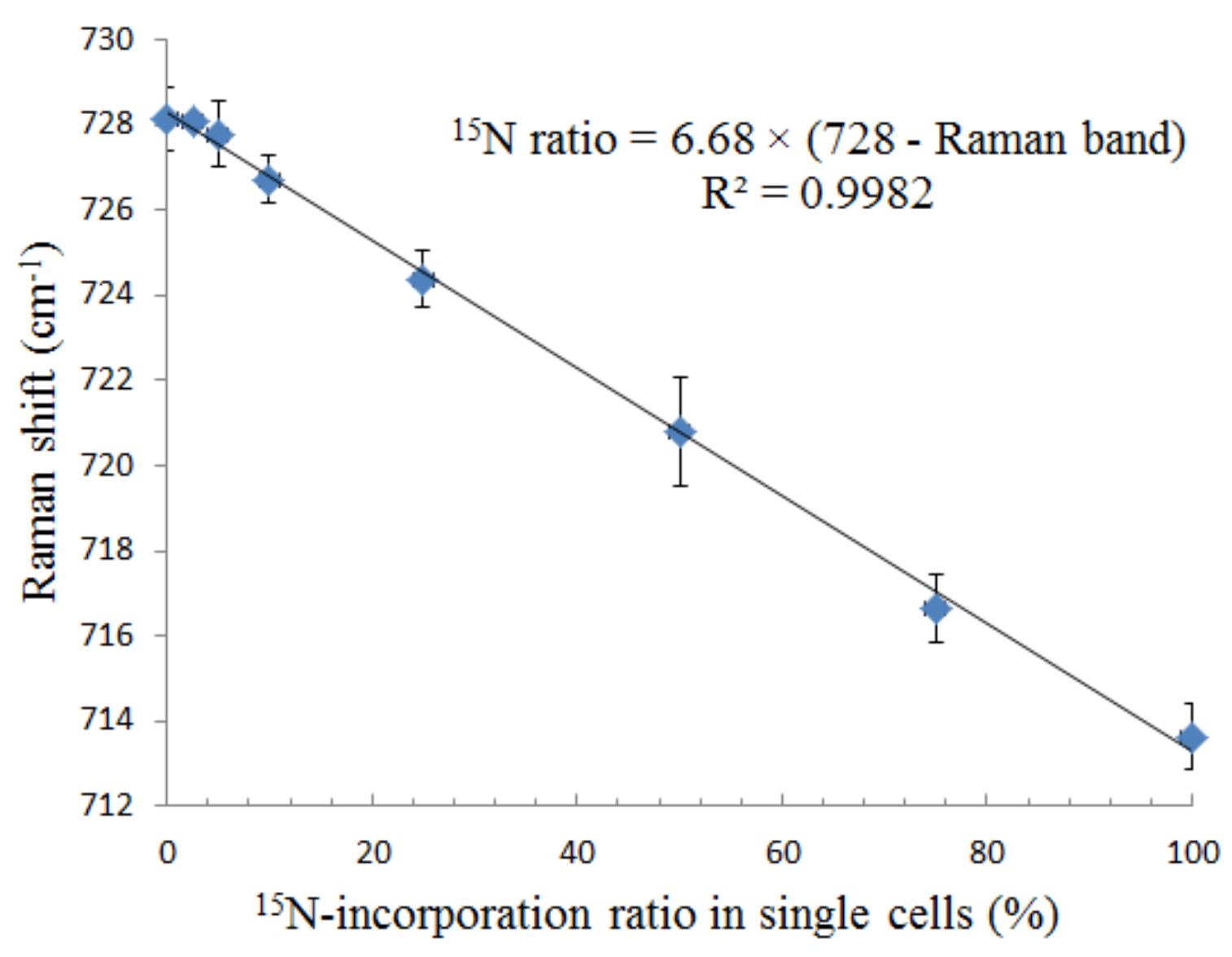




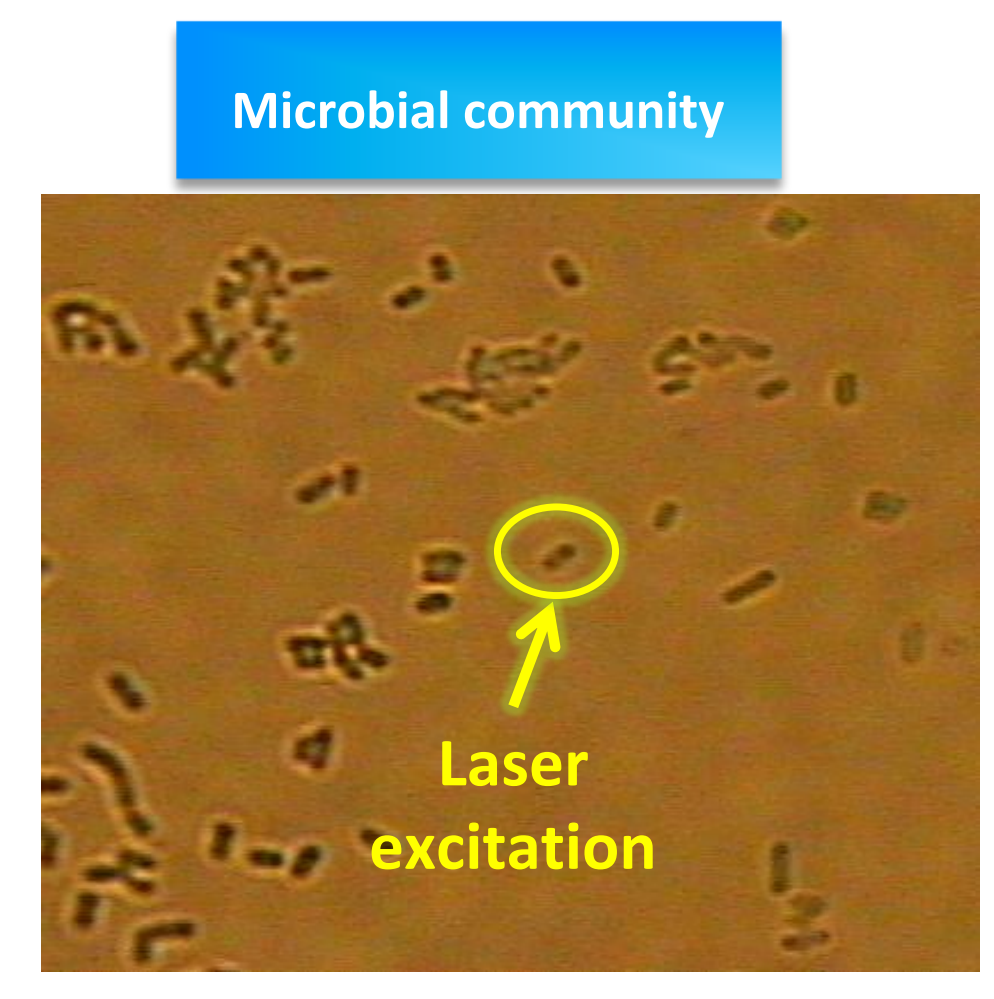

Raman-SIP revealing phenotypic profile
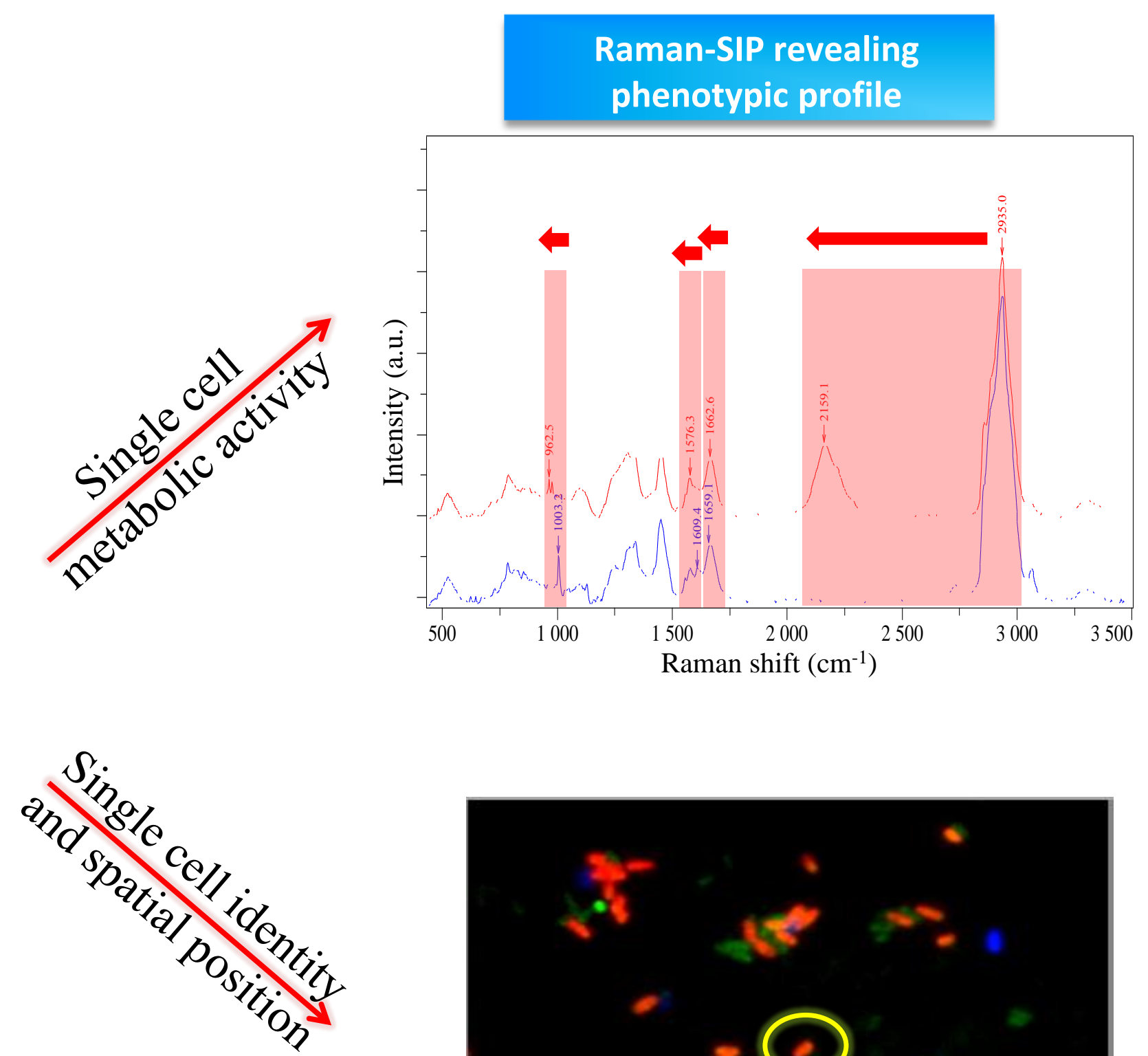

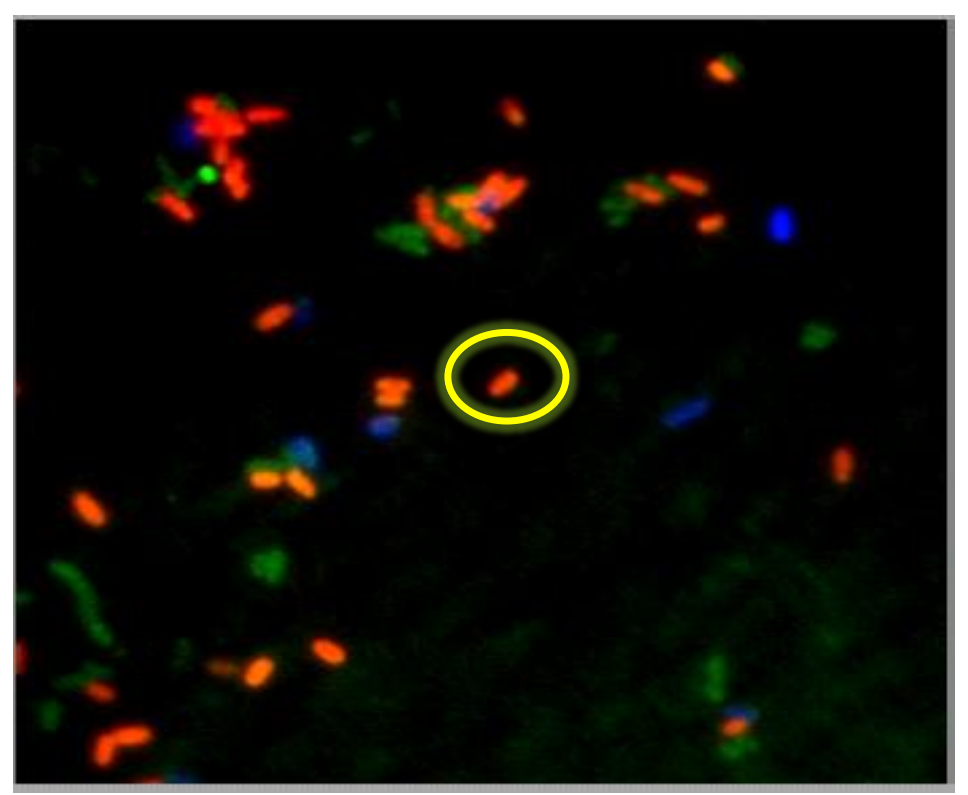

FISH probing

phylogenetic identity 